\title{
DOI https://doi.org/10.36059/978-966-397-241-1-6
}

Іванова I. B.

кандидат педагогічних наук, доцент, доцент кафедри економіки, підприємнищтва та маркетингу

Черкаський державний бізнес-коледж м. Черкаси

\section{ЗАБЕЗПЕЧЕННЯ КУЛЬТУРОВІДПОВІДНОСТІ ПРОФЕСІЙНОЇ ІНШОМОВНОЇ ОСВІТИ}

Дослідження присвячено проблемі культурологічного оновлення змісту професійної освіти. У процесі дослідження розглянуто взаємопов'язану зі змістом освіти категорію «зміст навчання професійного іншомовного спілкування». З'ясовано, що його компонентами є сфери спілкування, теми, ситуації; мовний, мовленнєвий, країнознавчий та лінгвокраїнознавчий матеріал; знання, навички та вміння спілкування. У результаті вивчення проблеми формування професійної компетентності майбутніх фахівців визначено основні їі компоненти, до яких належать: мотиваційний, когнітивний, діяльнісний, особистісно-оцінювальний, емпатичний. Автор виокремлює методи діагностування рівнів сформованості професійної іншомовної культурологічної компетентності здобувачів освіти. Розроблено критерії оцінювання та ілюстративні дескриптори для визначення рівнів сформованості професійної іншомовної культурологічної компетентності.

\section{Вступ}

Причиною підвищеної уваги до культурологічного спрямування процесу навчання іноземних мов у вітчизняній методиці стали соціальні, політичні та економічні зміни, що відбуваються в європейському просторі і не могли не торкнутися системи вищої освіти. У документах ООН, ЮНЕСКО, Ради Європи підкреслюється, що освіта XXI століття повинна сприяти тому, щоб людина могла усвідомити свої національні корені й з повагою ставитися до інших народів і культур.

Загальновідомим є факт невід'ємності понять мови і культури, оскільки навчання іншомовного спілкування не може обмежуватися 
лише знаковою системою, тому що кожна мова несе в собі інформацію про культуру, історію, традиції країни, мова якої вивчається.

Сучасна економічна ситуація в Україні, зростання багатонаціонального співробітництва сприяють підвищенню актуальності питання підготовки фахівців бізнес-сфери (менеджерів виробничої сфери, менеджерів туризму, менеджерів медичного обслуговування, економістів, юристів тощо), які здатні спілкуватись іноземною мовою, налагоджувати професійні контакти, досягати взаєморозуміння у діалозі культур сучасного ділового світу. За цих умов необхідною стає позиція раціонального поєднання культурологічного та професійного аспектів у навчанні іншомовного спілкування. Суть цього полягає в тому, що майбутній фахівець бізнес-сфери повинен пройти відповідну мовну підготовку як професійну, так і культурологічну, не ізольовано, а в синтезі першого і другого аспектів.

Знання іноземної мови та наявність умінь і навичок спілкуватися нею ще не свідчать про позитивне розв'язання проблеми встановлення порозуміння у професійних і партнерських стосунках. Щоб таке порозуміння справді відбулось і мало позитивний результат, необхідні ще й інші чинники.

Подолання комунікативних перешкод під час навчання іншомовного спілкування може мати місце лише у випадку досягнення культурологічної компетентності, що $\epsilon$ продуктом діалогу культур. За наявності культурологічної компетентності студенти, спілкуючись 3 носіями мови чи читаючи автентичні тексти, не будуть піддаватися фрустрації, неприємному здивуванню чи переживати культурний шок.

Як засвідчує власний педагогічний досвід, залучення майбутніх фахівців до професійних фрагментів іншомовної картини світу суттєво обмежене відсутністю в їхній картині світу багатьох стереотипних ситуацій спілкування, дискурсивних стратегій, професійних концептів, властивих соціуму країни, мова якої вивчається. Багато труднощів під час навчання іншомовного спілкування викликають такі ситуації ділової комунікації, як налагодження особистих контактів, працевлаштування, написання ділових листів, розмови по телефону, проведення зустрічей, переговорів, поїздка у відрядження та ін. Ця обставина змушує звернути особливу увагу на формування у здобувачів вищої освіти, майбутніх фахівців, професійної культурологічної іншомовної 
компетентності. Компонентний склад професійної іншомовної культурологічної компетентності ще остаточно не оформився як стандартний модуль, оскільки продовжує бути предметом наукових суперечок і дискусій.

\section{1. Культурологічне оновлення змісту навчання професійного іншомовного спілкування}

Узагальнюючи чинні підходи до визначення компонентного складу професійної компетентності, можна стверджувати, що професійна іншомовна культурологічна компетентність складається 3 таких компонентів: мотиваційного (мотиви, потреби), когнітивного (знання мови, культури, фаху), діяльнісного (навички, уміння, досвід), особистісно-оцінювального (професійні якості, самооцінка, самоаналіз), емпатичного (готовність до спілкування, позитивне ставлення до культури, толерантність). Однак змістове наповнення кожного з них для фахівця певного профілю потребує уточнення і деталізації.

Останнім часом великої актуальності набуває проблема оновлення змісту навчання іноземних мов як засобу міжкультурної комунікації. Основне завдання такого оновлення полягає у наповненні соціокультурної складової рисами культурологічного підходу [1, с. 155]: вироблення толерантності до представників інших культур; вироблення неупередженості до інформації; вироблення ідеологічної нейтральності; життєву орієнтацію та практичну спрямованість; врахування індивідуальних особливостей; розвиток здатності до емпатії та сприйняття чужого; порівняння культурних явищ, властивих народові, чию мову вивчають, з культурою свого народу, взаємодія мов; спрямування на різне соціальне і етнічне тло комунікантів; добір навчальних матеріалів з урахуванням особливостей багатокультурної аудиторії; спрямування на уникнення стереотипів.

Актуальним для нашого дослідження вважаємо структуру змісту полікультурної освіти, розроблену Р.Р. Агадулліним [2, с. 27-28]:

- розвиток соціокультурної ідентифікації як умова розуміння $\mathrm{i}$ входження в полікультурне середовище;

- опанування основними поняттями, що визначають розмаїття світу;

- виховання позитивного емоційного ставлення до розмаїття культур;

- формування вмінь, складових поведінкової культури світу. 
Оскільки мова - явище соціальне, і єдиним джерелом, з якого можна почерпнути зміст навчання, $\epsilon$ культура, то, на наш погляд, культурологічний підхід повинен наскрізно пронизувати зміст навчання іншомовного спілкування і бути присутнім у всіх його компонентах.

Загальновідомим $є$ факт, що компонентний склад змісту навчання іноземної мови змінювався у процесі розвитку теорії навчання, відображаючи собою соціальне замовлення суспільства. Соціальне замовлення держави на сучасному етапі спрямовано на підготовку компетентних фахівців усіх галузей економіки. Нове соціальне замовлення сучасного суспільства вимагає не тільки навчати іноземної мови як засобу спілкування, а й формувати багатомовну особистість, яка поєднує у собі цінності рідної та іншомовної культур і готова до міжкультурного спілкування. Як зазначає В. Бушкова, динаміка розвитку міжкультурних контактів, осмислення масштабів активного та потенційного простору спілкування особистостей на межі культур спонукає до переорієнтації процесу навчання іноземних мов з форми на функцію, з лінгвістичної компетенції на соціокультурну [3, с. 120]. Культурологічні та лінгвосоціопсихологічні знання про іншомовний соціум, які створюють широкий контекст міжкультурного спілкування, формують готовність до ефективного міжкультурного ділового спілкування і відповідно до міжнародного професійного співробітництва.

У процесі міжкультурного спілкування комуніканти вступають у соціальні стосунки, які виникають у певній сфері діяльності, потреба і бажання спілкуватися виникає у певній ситуації. Унашому дослідженні ми спираємось на положення Загальноєвропейських Рекомендацій з мовної освіти. Автори Загальноєвропейських Рекомендацій з мовної освіти виділяють чотири сфери у контексті головних цілей процесів вивчення та викладання [4, с. 45]:

- особистісну (сферу особистих інтересів), в якій суб'єкт навчання живе як приватна особа. Центром цієї сфери є дім, сім'я, друзі;

- публічну, в якій суб'єкт навчання діє як член загальної спільноти або певної організації і виконує різноманітні види діяльності з різними цілями;

- професійну, в якій суб'єкт навчання виконує свої професійні обов'язки;

- освітню, в якій суб'єкт навчання бере участь в організованому навчальному процесі, особливо (але не обов'язково) у певній освітній установі. 
Очевидно, що в процесі навчання професійного іншомовного спілкування відбувається взаємопроникнення цих сфер, і жодна 3 них не може розглядатись ізольовано.

Згідно з завданнями нашого дослідження, навчання професійного іншомовного спілкування повинно розвивати теми в галузі занять та професій, релевантних для майбутнього профілю здобувачів освіти. Під час добору тем культурологічного характеру йдеться не просто про систематичну презентацію країнознавчих знань щодо країни, мова якої вивчається, а про необхідність навчитись бачити іншу культуру з позицій того, хто навчається. В іншому випадку студенти можуть отримати ті знання, які будуть більше вводити в оману, ніж інформувати.

Для професійної сфери характерні такі форми іншомовної діяльності як телефонні розмови, складання офіційно-ділової документації (в основному різних видів ділових листів таких як лист-запит, лист-пропозиція, лист-замовлення, лист-рекламація, лист-запрошення, лист-подяка та ін.), укладання договорів зовнішньоекономічної діяльності, офіційні та неофіційні зустрічі з іноземними діловими партнерами, участь у роботі міжнародних виставок та ярмарок, обговорення умов контракту купівлі-продажу, обробка та складання рекламних повідомлень. Все це вимагає від студентів використання тезауруса та об'єктивних відомостей, які торкаються іншої культурної дійсності, 3 різносторонньою культурологічною інформацією. Досягти цього можна за допомогою формування у свідомості здобувачів освіти образу ситуації, на основі якої здійснюється регуляція мовленнєвої поведінки. Загальноєвропейські Рекомендації описують ситуації за такими параметрами: місце і час, де/коли вони відбуваються; установи або організації, структури та заходи яких контролюють більшість з того, що, як правило, відбувається; дійові особи, особливо у їх відповідних соціальних ролях у відношенні до користувача/того, хто вивчає мову; об'єкти (живі та неживі) навколишнього середовища; операції, що виконуються дійовими особами; текстами, що зустрічаються у межах ситуації.

Останнім часом у зарубіжній дидактиці поряд із категоріями теми, ситуації, тексту з'явились категорії «культурних схем», «культурних моделей» та «сценарію». Так, Р.Г. Андрад під «культурними схемами» розуміє одиниці організації набору артефактів (найменших складових культури, які виникають в процесі перетворення оточуючого світу) [5]. Загальним для суб'єктів культурним схемам 
він дає визначення «культурні моделі». Найбільшого рівня досліджуваності серед зарубіжних науковців досяг один із видів культурних моделей, який називається «сценарії» або «фрейми» (Т.А. ван Дейк, I.I. Халєєва та ін.). Вони розглядають сценарій як репрезентацію чи стратегію розуміння подій, ситуації, комунікативні акти в контексті національної культури. При цьому особливого значення набуває поняття «пресуппозиції», яку визначають як побудову своєї мовленнєвої поведінки відповідно до очікувань партнера. 3 цього положення визначається необхідність співвіднесення конкретної ситуації з певним культурним сценарієм ситуації, що існує в свідомості людини з власними схематичними асоціаціями.

Ще одним важливим елементом змісту навчання $\epsilon$ знання. До культурологічних знань належать енциклопедичні та фонові знання. Прийнято вважати, що енциклопедичні знання включають активне ознайомлення з культурною картиною світу як певної системної цілісності, а також наявність досвіду вивчення динаміки ціннісних орієнтацій країн, які порівнюються. Як правило, ці знання отримують ще під час навчання у загальноосвітніх школах та продовжують їх поповнювати та удосконалювати у вищих навчальних закладах у курсі гуманітарних дисциплін.

На нашу думку, особливої уваги під час навчання іншомовного спілкування заслуговують фонові знання. У процесі спілкування присутні різні типи фонових знань. Зання, якими володіють лише члени певної етнічної та мовної спільноти, найбільше пов'язані 3 національною культурою і представляють інтерес для навчання іншомовного спілкування. Наявність фонових знань загальнолюдського та регіонального характеру дають змогу учасникам комунікації певною мірою розуміти одне одного, але лише володіння культурологічними фоновими знаннями дозволяє їм досягати повного взаєморозуміння в діалозі культур. Саме тому навчання культурологічних фонових знань повинно бути невід'ємною частиною змісту навчання іншомовного спілкування. Ці фонові знання включають: 1) знання загальноприйнятих в країні норм поведінки (етикету) або комунікативних моделей поведінки; 2) знання культурних реалій.

Комунікативні моделі поведінки можуть бути вербальними, невербальними та змішаними. До професійно орієнтованих вербальних моделей належать: форми звернення до ділових партнерів; норми поведінки під час влаштування на роботу; норми 
заповнення анкет та написання автобіографій; етикет телефонної розмови; правила написання ділового листа; правила ведення ділових зустрічей та переговорів. Моделі невербальної поведінки включають: паралінгвістичні (інтонація, паузи, дикція, темп, гучність, ритміка, тональність, мелодика та ін.); екстралінгвістичні (різні шуми, сміх, плач тощо); кінестетичні (жести, міміка, контакт очей); проксематичні (пози, рухи тіла, дистанція, тобто просторочасова організація спілкування). Під час навчання професійного іншомовного спілкування уваги вимагає навчання культурологічних комунікативних рухів, особливо кінем, які не співпадають у виконанні чи змісті в різних ситуаціях ділового спілкування.

Знання реалій включають уяву про предмет або явище, характерне для історії, культури, побуту, устрою життя конкретної культурної і мовної спільноти. Словом «реалія» позначають, головним чином в філологічних текстах, предмети матеріальної культури, які виступають основними для номінаційного значення слова. 3 іншого боку, в перекладознавстві, лінгвокраїнознавстві терміном «реалія» позначають здебільшого слова, які називають такі предмети і поняття. Але якщо мовні засоби вже достатньо вивчені та розподілені за етапами навчання залежно від цільових установок, то культурологічні фонові знання ще не достатньо досліджені та описані. Одна з головних труднощів їх добору - це визначення меж, тобто, що зараховувати до фонових знань. Адже не всі знання про культуру країни належать до культурологічних фонових знань, а лише ті, що актуальні для працівників певної сфери, і маловідомі іноземцям.

Наприклад, важливим є знання реалій для фахівців рекламної діяльності, оскільки для того, щоб реклама була успішною і принесла очікувані результати, вона повинна відповідати нормам культури даної спільноти. Велика Британія, наприклад, має жорсткі обмеження у рекламі алкогольних напоїв, у деяких ісламських країнах заборонено використовувати в рекламі фотографії чи живі зображення, а лише малюнки. Показовим $є$ приклад рекламної кампанії, яка була провалена, через некоректне використання кольору, який виявився скорботним у країні, де рекламувався товар.

Фонові знання, як ілюструють наведені приклади, реалізуються, насамперед, в лексиці, оскільки саме лексика як першоелемент спілкування відтворює дійсність та швидко реагує на всі зміни суспільного життя. Окрім концептуального ядра, у склад лексичного значення слова входять так названі конотації - додаткові значення: 
емоційні, експресивні, стилістичні добавки до основного значення, які надають слову особливого забарвлення.

Окрім безеквівалентної та конотативної лексики, до слів 3 культурним компонентом відносять також фонову лексику іншомовні одиниці, що відрізняються лексичними фонами (рівень лексичного поняття при цьому співпадає) від лексики рідної мови. Лексичні фони мови, як правило, тісно пов'язані з сукупністю всіх цінностей духовної культури суспільства, тому навіть слова далекі від національних особливостей варто уважно вживати в мові. Наприклад, слова «компанія», «корпорація» не можна назвати безеквівалентними для іноземних мов, тому що їх легко перекласти, але вся сукупність відомостей про них, наприклад, у Великій Британії, відрізняється від лексичного фону української компанії чи американської корпорації. Ці іншомовні фонові відомості відтворюють специфіку системи британського бізнесу і показують характерні риси іншого способу життя. Крім того, лексика 3 національно-культурним компонентом може бути представлена ще i фразеологізмами, яких також не слід уникати у навчанні професійного іншомовного спілкування. Правильне їх тлумачення i відповідна реакція можуть бути досить важливими під час проведення, наприклад, ділових переговорів з метою обговорення умов контракту тощо. Незнання i некоректне розуміння фразеологізмів, як, наприклад, cross your t's (поставити крапки над «i»), that is a horse of another colour (це зовсім інша справа), that's where the shoe pinches (ось в чому заковика), to buy a pig in a poke (купувати кота в мішку), to make a mountain out of a molehill (робити з мухи слона), take care of the pence and the pounds will take care of themselves (копійка гривню береже) та ін., може створити певні перешкоди у ситуаціях міжкультурного ділового спілкування.

Здійснений аналіз філософської та дидактичної літератури 3 досліджуваної проблеми дозволяє визначити основні властивості культурологічних умінь. Полем їх застосування $€$ соціокультурна сфера. Культурологічні уміння - це узагальнюючі способи оперування соціогуманітарними знаннями, поняттями, уявленнями в різноманітних умовах пізнавальної та практичної діяльності. Вони інтегруються в різноманітні види діяльності (культурно-освітню, соціальну, екологічну, організаційно-управлінську, економічну). Вони активно впливають на духовний та інтелектуальний потенціал особистості.

Культурологічні вміння розглядаються як інтелектуальні вміння, за допомогою яких здійснюється орієнтація в соціокультурній сфері, 
відбувається осмислення культурологічних явищ, формується уявлення про різноманітні аспекти культури і культуротворчої діяльності; визначаються принципи взаємозв'язку мови і культури; аналізуються, зіставляються, узагальнюються явища і факти у контексті культури.

Ймовірно, що ефективність формування професійної іншомовної культурологічної компетентності здобувачів підвищується, коли навчальні засоби залучені до процесу навчання в комплексі: друковані матеріали (тексти), аудитивні, аудіовізуальні, ілюстративні. Роботу над навчальним матеріалом слід, на нашу думку, організовувати в такий спосіб, щоб зосередити увагу студентів на сприйнятті їх з позицій культурологічного підходу, тобто розуміти текст $з$ установкою на пізнання країни, мова якої вивчається, її культури. Навіть, якщо в основу покладена діяльність, спрямована на засвоєння лексичного чи граматичного матеріалу, то тексти культурологічного характеру можуть виконувати функцію ілюстрації цих мовних одиниць у спілкуванні. Тому під час добору навчальних матеріалів необхідно враховувати їх культурологічну спрямованість.

Усі автентичні матеріали ми пропонуємо диференціювати на:

- $\quad$ автентичні, тобто ті, що залучені з оригінальних джерел, не призначених для навчальних цілей, характеризуються природністю лексичного наповнення i граматичних форм, ситуативною адекватністю мовних засобів і ілюстрацією автентичного вживання;

- навчально-автентичні, тобто ті, що спеціально розроблені методистами, укладачами підручників та навчальних посібників 3 урахуванням усіх параметрів автентичного навчального процесу, критеріїв автентичності та призначені для конкретних навчальних цілей.

На нашу думку, цінність автентичних текстів полягає у можливості отримати пізнавальну i цікаву культурологічну інформацію; створити культурний портрет представника іншої культури; зрозуміти стереотипи поведінки, які проявляються в конкретних життєвих ситуаціях; порівняти явища іншомовної культури з рідною.

Прагматичні матеріали заслуговують на особливу увагу. Вони не $\epsilon$ суто навчальними, а створені виключно для користування носіями мови. До них належать автентичні зразки друкованої інформації, такі як оголошення, анкети, вивіски, етикетки, проїзні квитки, меню, рахунки, рекламні проспекти, розклади руху потягів та авіарейсів, 
путівники, зображення грошових купюр, візитівки, тощо. Такі матеріали не лише несуть важливе інформаційне навантаження, але i $\epsilon$ достовірними джерелами, що стимулюють справжню міжкультурну комунікацію, в якій здобувачі освіти мають певні ролі, переживають події, вирішують проблеми. Прагматичні матеріали підвищують мотивацію студентів, формують та задовольняють їхні пізнавальні інтереси і в такий спосіб вводять їх в іншу лінгвокультуру.

Своєрідність культурологічно-маркірованого мовного матеріалу, а саме позначення понять, відсутніх в інших культурах (безеквівалентна лексика), або відображення особливостей національної культури (фонова лексика) вимагає і відповідних прийомів його презентації та семантизації. Важливого значення під час роботи 3 автентичними матеріалами набувають коментарі культурологічних реалій. Вони повинні бути стислими, викладати найнеобхіднішу інформацію і можуть подаватися рідною або іноземною мовою. Ми вважаємо, що спочатку слід звертати увагу здобувачів на подібні культурні елементи, а вже потім розглядати розбіжності. 3 урахуванням іншомовного досвіду здобувачів коментарі можуть бути і більш розгорнутими.

Аналіз лексичних одиниць, необхідних для розкриття будь-якої теми культурологічного характеру, свідчить, що багато 3 них відображають ключові поняття, які можна розкрити через супроводжуючі їх поняття-супутники, що формують їх тло. Такі особливості лексики вимагають пошуку відповідних прийомів іï подачі, які б у доступній та наочній формі допомогли студентам усвідомити ці структурно-смислові зв'язки. Огляд методичної літератури засвідчив, що таким прийомом $\epsilon$ асоціограма, яке передбачає поступове нарощування тла будь-якого ключового поняття, що засвоюється.

3 урахуванням повноти розкриття лексичного тла ключового поняття можна будувати асоціограми різного типу. Вважаємо, що поєднання коментарю як прийому семантизації понять, відсутніх у рідній культурі, або які мають певні національні особливості, 3 одночасною побудовою їх наочного схематичного образу у формі асоціограми, буде сприяти як глибшому розумінню явищ іншомовної культури, так і кращому їх засвоєнню.

Власний педагогічний досвід засвідчує, що у системі вправ i завдань недостатньо реалізовується культурологічний підхід до навчання професійного іншомовного спілкування. У сучасній 
дидактиці загальноприйнятою $є$ система вправ i завдань, яка складається 3 чотирьох підсистем для оволодіння навичками і вміннями певного виду мовленнєвої діяльності - аудіювання, читання, говоріння і письма. Як свідчать результати проведеного нами дослідження, оволодіння культурологічними знаннями може і повинно здійснюватися одночасно 3 формуванням навичок i розвитком умінь у різних видах мовленнєвої діяльності. Наприклад, у підсистемі вправ для навчання аудіювання та читання позитивно зарекомендувало себе використання мовних вправ на розуміння культурологічно-маркіровних лексичних одиниць, докомунікативних на активізацію одиниць і контроль розуміння сутності культурологічних категорій.

На нашу думку, презентація і семантизація культурологічного матеріалу під час навчання професійного іншомовного спілкування може здійснюватись у різний спосіб відповідно до конкретної лексичної одиниці, а саме:

1. Семантизація лексики, яка розкриває фонову інформацію, повинна здійснюватись шляхом пояснення особливостей функціонування форм, предметів і їхнього призначення. Продуктивними прийомами є паспортизація (тематичний запис слів з коментарями) і порівняння, описання подібних явищ і реалій культури іноземної і рідної мов.

2. Добір і семантизація безеквівалентної лексики передбачає описовий коментар шляхом тлумачення чи паспортизацію.

3. Конотативна лексика не передбачає ні переклад, ні наочну семантизацію. Основним прийомом може слугувати культурологічний описовий коментар, тлумачення, паспортизація ключових слів за темами.

4. Навчання невербальної поведінки або соціокомунікації та оволодіння комунікативними моделями поведінки передбачає пояснення, закріплення в комунікативних завданнях і рольових іграх.

5. Робота з фразеологізмами передбачає тлумачення, добір еквівалента, який функціонує в рідній мові.

Для розвитку вмінь читати тексти культурологічного характеру ми рекомендуємо комплекс вправ, який базується на матеріалі текстів різних жанрів. За результатами нашого дослідження найефективнішими, а відтак такими, що підвищують мотивацію студентів, виявились пізнавально-інформаційні тексти. Вважаємо, що особливу увагу у цьому комплексі вправ необхідно приділяти 
зіставленню реалій рідної та іншомовної культур, без чого неможливе ефективне формування іншомовної культурологічної компетентності.

Підсистема вправ і завдань для навчання говоріння включає три їх види. Мовні вправи спрямовані на формування лексичних навичок говоріння, в той час як докомунікативні вправи та комунікативні завдання - на розвиток мовленнєвих умінь говоріння у діалогічній та монологічній формах. Такі вправи і завдання сприяють підготовці майбутніх фахівців до ділового діалогу, в якому партнери - це уявні представники різних зарубіжних компаній, фірм, підприємств 3 іноземними інвестиціями, інвестори різних проектів в Україні, а місце діалогу - переговори, виставки, форуми, конференції, презентації. Варто врахувати, що мовленнєві ситуації у різних сферах спілкування неоднорідні за своїм змістом. Так, якщо в соціальнопобутовій сфері (наприклад, відвідування ресторану чи магазину), це моноситуації, то в професійній сфері (участь у виставці, презентація продукції, відвідування фірми партнера) - це політеми. Тому, на нашу думку, доцільно звернути увагу на використання ситуативних завдань і дидактичної ділової гри, які містять у собі великі можливості для підготовки студентів до вирішення професійних та мовних проблем. Результати дослідження свідчать про необхідність розробки вправ і завдань на усунення культурологічних бар'єрів на основі моделювання типових комунікативних ситуацій. Великий потенціал мають завдання проблемного характеру. Вони спонукають студентів самостійно мислити, висловлювати свою думку, генерувати нові ідеї, адаптуючись до іншої лінгвокультури.

у підсистемі вправ для навчання письма ми пропонуємо акцентувати увагу на мовні вправи на формування навичок і вмінь використовувати культурологічно-маркіровані лексичні одиниці у письмі та комунікативні завдання на розвиток умінь письма. Як одну 3 ефективних етикетно-узуальних форм зарекомендувало себе листування, тому навчальні матеріали повинні містити зразки ділових листів: запитів, замовлень, подяк, запрошень тощо. У такий спосіб культурологічна інформація представлена в природній формі.

У зв'язку 3 необхідністю здійснювати опору на рідну мову і культуру доцільно передбачити можливість зіставлення культурологічних реалій. Слід зауважити, що існують два способи презентації культурологічного матеріалу, які дають змогу зіставляти свою та іншомовну культури: з позицій представника 
країни, мова якої вивчається; з позицій гостя країни, мова якої вивчається. У першому випадку відтворюється контекст діяльності носія іншої лінгвокультури, а студент спостерігає за його пересуваннями по країні. У другому випадку фахівець рідної країни відправляється у відрядження в англомовну країну, а студент знайомиться 3 культурологічними реаліями країни, мова якої вивчається, крізь призму сприйняття цього фахівця: проходить культурну адаптацію, спостерігає за загальноприйнятими нормами поведінки тощо. На нашу думку, ефективнішим для навчання професійного іншомовного спілкування 3 урахуванням культурологічного підходу є другий принцип, хоча на просунутому етапі навчання можливе використання і першого.

\section{2. Критерії та методи оцінювання, ілюстративні дескриптори для визначення рівнів сформованості професійної іншомовної культурологічної компетентності}

У ході дослідження з'ясовано, що про ефективність культуровідповідності професійної іншомовної освіти свідчать рівні сформованості професійної іншомовної культурологічної компетентності студентів і готовність майбутніх фахівців немовних спеціальностей до участі у міжкультурному діловому спілкуванні.

Професійна іншомовна культурологічна компетентність складається 3 таких компонентів: когнітивного (знання мови, культури, фаху), діяльнісного (навички, уміння, досвід), мотиваційного (мотиви, потреби), особистісно-оцінювального (професійні якості, самооцінка, самоаналіз), емпатичного (готовність до спілкування, позитивне ставлення до культури, толерантність). Для іï успішного та ефективного формування необхідний ряд дидактичних умов, які забезпечать досягнення поставленої мети. Під дидактичними умовами формування професійної іншомовної культурологічної компетентності ми розуміємо сукупність чинників, що зумовлюють цей процес і забезпечують його успішний розвиток. До них ми відносимо: застосування комплексу підходів до навчання професійного іншомовного спілкування, домінуючим серед яких є культурологічний підхід; реалізація культурологічного підходу у змісті навчання; здійснення опори на рідну культуру студентів з метою організації процесу навчання як діалогу культур; орієнтація на формування міжкультурної свідомості студентів.

Перша виділена дидактична умова передбачає застосування комплексу підходів, керуючись тим, що процес навчання 
професійного іншомовного спілкування $\epsilon$ багатоаспектним механізмом. Враховуючи тему нашого дослідження, в основі знаходиться культурологічний підхід, який впливає на всі компоненти і відтворює тісний взаємозв'язок мови і культури. Компетентнісний підхід пов'язаний із формуванням професійної іншомовної культурологічної компетентності майбутніх фахівців будь-якої галузі. Комунікативно-діяльнісний підхід означає орієнтацію компонентів змісту навчання на підготовку студентів до професійної діяльності з урахуванням можливих сфер і ситуацій іншомовного спілкування.

Застосування вищеокресленого комплексу підходів тісно пов'язане 3 іншими дидактичними умовами. Реалізація культурологічного підходу у змісті навчання дасть змогу максимально охопити культурологічні категорії, характерні для професійних ситуацій та в поєднанні мовних елементів 3 елементами культури познайомити студентів 3 новою для них дійсністю. Здійснення опори на рідну культуру сприятиме кращому сприйняттю іншої ментальності та стереотипів іншого світу через власну картину світу, забезпечує розвиток здатності представити свій світ представникам іншої культури.

Ще однією важливою дидактичною умовою вважаємо орієнтацію на формування міжкультурної свідомості, яка полегшує усвідомлення культурних розбіжностей між своєю та іншомовною культурами, позитивно впливає на підготовку студентів до міжкультурного спілкування та розвиток їхньої толерантності до представників іншої культури.

Наступна умова полягає у доборі автентичних навчальних матеріалів, їх актуальності, типовості, контрастивності, узгодженості і позитивному потенціалі.

Культурологічна іншомовна підготовка студентів буде ефективною, як нами доведено, лише у тому випадку, коли навчальні матеріали міститимуть фрагменти, які з'явились в реальних ситуаціях спілкування у тому соціумі, мова якого вивчається, тобто відповідно до вимоги автентичності. Вимога актуальності передбачає відтворення сучасної стадії соціальнорольової взаємодії учасників міжкультурного спілкування. Відповідно до вимоги типовості навчальні матеріали повинні бути джерелом типової культурологічної інформації, містити стандартизовані мовленнєві зразки, які регулярно повторюються в ситуаціях міжкультурного спілкування. Вимога узгодженості 
відображає положення про те, що зміст навчання повинен забезпечувати формування культурологічної компетентності студентів, узгоджуючись з їхніми професійними комунікативними потребами. Ми керувались також вимогою контрастивності, яка полягає в організації навчання в порівняльному плані з метою сприяння усвідомленню подібностей і розбіжностей у рідній та іншомовній культурах. Вимога позитивного потенціалу передбачає виховання позитивного ставлення та поваги до іншої лінгвокультурної спільноти. При цьому позитивне ставлення до країни - це не реклама, а забезпечення емоційного клімату, усунення психологічних перешкод у спілкуванні, допомога студенту в запам'ятовуванні предметно-логічної інформації.

У процесі дослідження нами були окреслені можливості моніторингу як дієвого механізму формування і розвитку у студентів вищих немовних закладів освіти професійної іншомовної культурологічної компетентності майбутнього фахівця. Аналіз вітчизняної і зарубіжної педагогічної літератури підтверджує особливий інтерес у науковців різних країн до педагогічного моніторингу, який трактується як тривале спостереження за процесом інтеграції психолого-педагогічних знань в усіх його станах і виявах, співвіднесення одержаної інформації із заданим еталоном i прогнозуванням на цій підставі нового технологічного забезпечення цього процесу [6]. У контексті нашого дослідження ми розглядаємо моніторинг як цілісний процес, що полягає у діагностиці професійної іншомовної культурологічної компетентності. Систему моніторингу ми розуміємо як систему діагностичних процедур, що забезпечують спостереження за динамікою розвитку професійної компетентності фахівця бізнес-сфери.

Анкетне опитування працівників фірм і компаній, які ведуть бізнес із зарубіжними партнерами мало на меті перевірку нашого припущення про необхідність культуровідповідної підготовки майбутніх фахівців. Анкети містили чіткі і лаконічні запитання із можливими варіантами відповідей. Результати анкетного опитування були опрацьовані за допомогою програми Microsoft Excel. Ïx аналіз свідчить про те, що за умов міжмовних контактів знання граматичних і лексичних норм мови не завжди $є$ достатніми. $80 \%$ фахівцям доводилося часто стикатись із культурологічними проблемами під час ведення бізнесу 3 представниками іншої культури. На запитання «Чи доводилось Вам переживати культурний шок під час спілкування з іноземними партнерами?» 
більшість респондентів (75\%) дали позитивну відповідь. Важливо зазначити, що у $68 \%$ опитуваних ці проблеми були пов'язані 3 професійними ситуаціями. Відсутність знань про правила ведення професійного діалогу, етикету ділових стосунків зашкодила їм досягненню цілей.

3 метою вивчення найчастотніших культурологічних проблем, 3 якими доводиться зустрічатись у своїй роботі фахівцям бізнессфери, нами були запропоновані запитання на уточнення сфер застосування культурологічних знань і умінь. Запитання анкети містили найважливіші культурологічні аспекти професійного іншомовного спілкування, а саме: проблеми, пов'язані з культурою поведінки, культурою спілкування, незнанням традицій, незнанням культурної спадщини, нерозумінням іншокультурної ментальності. Результати опитування засвідчили, що значні труднощі під час контактів 3 іноземними партнерами викликають проблеми, пов'язані з культурою спілкування (45\%). Друге місце посідають проблеми, пов'язані з незнанням традицій (25\%). Третє місце (22\%) - проблеми, пов'язані з культурою поведінки. Найменші відсотки (5\% і 3\%) культурологічних проблем, пов'язані із нерозумінням іншокультурної ментальності і незнанням культурної спадщини країни ділового партнера відповідно.

Як засвідчують результати анкетування, для успішних професійних контактів необхідні як знання мови, так і уміння володіти культурою спілкування, розуміння екстралінгвістичної ситуації і культури соціально-економічних відносин.

У результаті анкетного опитування студентів бакалаврського рівня було виявлено, що вони розуміють необхідність вивчення культури засобами іноземної мови, хоча і не віддають цьому перевагу на відміну від працівників фірм і компаній, які займаються зовнішньоекономічною діяльністю

Результати засвідчили, що $35 \%$ студентів вважають за найважливіше навчання лексики, 30\% - навчання усного спілкування, $20 \%$ - навчання граматики, $10 \%$ - навчання іншомовної культури, 5\% - навчання писемного спілкування. Найбільшу зацікавленість і необхідність студенти вбачають у оволодінні культурою ділового спілкування. $100 \%$ опитуваних виділили цей культурологічний аспект як пріоритетний.

Таким чином, результати анкетного опитування працівників фірм і компаній, які займаються зовнішньоекономічною діяльністю і студентів вищих немовних закладів освіти підтвердили наше 
припущення про необхідність забезпечення культуровідповідності змісту професійної іншомовної освіти.

Подальший перебіг дослідження передбачав визначення критеріїв оцінювання рівнів сформованості професійної іншомовної культурологічної компетентності студентів. Здійснений аналіз досліджень науковців (Л.С. Артамонової, І. Арановської, М.С. Кагана, В.О. Калініна, Ю.І. Пасова, Л.В. Сохань) з питань компонентного складу професійної іншомовної культурологічної компетентності дозволив нам окреслити критерії та їх показники, які характеризують рівні сформованості професійної іншомовної культурологічної компетентності студентів та які забезпечують можливість своєчасно коригувати хід професійної підготовки майбутніх фахівців. Нами прийняті такі критерії: мотиваційний, когнітивний, діяльнісний, особистісно-оцінювальний, емпатичний, названі відповідно до компонентів. Розглянемо детальніше кожний 3 них.

Об'єктами оцінювання мотиваційного критерію $\epsilon$ професійна мотивація та мотиви навчальної діяльності. До показників критерію відносимо сукупність мотивів, адекватних до цілей та завдань професійної діяльності; позитивне ставлення до професії, інтерес до неї; відповідальність за виконання завдань, почуття обов'язку.

Об'єктами оцінювання когнітивного критерію $€$ знання про мову; знання про культуру країни, мова якої вивчається; сформованість уяви про рідну та іншомовну культуру. Даний критерій пов'язаний із пізнавальною сферою людини. До показників належить сукупність знань, необхідних для продуктивної професійної діяльності.

Об'єктами оцінювання діяльнісного критерію $\epsilon$ навички оперування засобами спілкування; розвиток уміння організувати комунікативну діяльність. До показників відносимо рівень володіння способами та прийомами професійної діяльності, необхідними ключовими компетенціями.

Об'єктами оцінювання особистісно-оцінювального критерію $є$ сформованість особистісних професійних якостей; розвиток уміння самостійно оцінювати свою діяльність. До критеріїв належать сукупність особистісних якостей, важливих для виконання професійної діяльності; самооцінка своєї професійної підготовленості.

Об'єктами оцінювання емпатичного критерію $€$ відношення студента до мови та культури країни, мова якої вивчається. До показників відносимо позитивне ставлення до іншомовної 
культури, бажання сприймати і розуміти іншу культуру; толерантність та готовність до спілкування на міжкультурному рівні.

На основі шкал рівнів володіння мовою згідно 3 Загальноєвропейськими рекомендаціями ми умовно визначили три рівні сформованості професійної іншомовної культурологічної компетентності майбутнього фахівця (низький, середній і високий) та описали ілюстративні дескриптори («може робити»), що використовуються під час реалізації видів мовленнєвої діяльності.

Низький рівень характеризується слабкою професійною спрямованістю, недостатнім рівнем володіння професійно значущими культурологічними знаннями, невмінням використовувати їх у професійних навчальних ситуаціях. Здобувачі освіти пасивні, ігнорують необхідність оволодіння уміннями, важливими для організації ефективного міжкультурного спілкування. Здатність критично оцінити себе у багатьох здобувачів відсутня.

За видами мовленнєвої діяльності низький рівень має такі характеристики:

Аудіювання: може розуміти прості культурологічно-маркіровані одиниці, якщо мовлення достатньо чітке і повільне. Може розуміти основний зміст адаптованого аудіо/відео запису, зміст адаптованого аудіо/відео запису, який містить культурологічні реалії.

Читання: може читати та розуміти короткі тексти, які містять засвоєний культурологічний матеріал. Може виокремлювати загальну інформацію із прагматичних текстів (оголошення, меню, розклад руху поїздів, літаків тощо).

Говоріння: може починати, підтримувати та закінчувати бесіду 3 тем, пов'язаних з рідною та іншомовною культурами. Може будувати прості зв'язні висловлювання, використовуючи культурологічномаркіровану лексику. Може спілкуватись на простому побутовому рівні з дотриманням культури мовлення і поведінки.

Письмо: може написати особистий лист з використанням формул мовленнєвого етикету. Може заповнити анкету, написати автобіографію.

Середній рівень характеризується більш розвиненою професійною спрямованістю, мотивацією в оволодінні професією, зацікавленістю в культурологічних категоріях та знанням їх на достатньо хорошому рівні. Здобувачі освіти виявляють самостійну здібність до оволодіння іншомовною культурою, але не виявляють належної ініціативності у цьому процесі. Здатність до подальшої самоосвіти відсутня у багатьох здобувачів освіти. 
За видами мовленнєвої діяльності середній рівень має такі характеристики:

Аудіювання: може розуміти основний зміст різнопланових текстів, які містять культурологічно-маркіровані одиниці. Може виділяти необхідну інформацію з різних джерел: оголошень, повідомлень, із ситуативних діалогів та інтерв'ю тощо.

Читання: може знаходити культурологічну інформацію відповідно до завдання. Може розуміти прагматичні тексти (оголошення, меню, розклад руху поїздів, літаків тощо).

Говоріння: може запитувати і відповідати простими репліками 3 тем, пов'язаних з рідною та іншомовною культурами. Може розпізнавати та використовувати у мовленні просту культурологічно-маркіровану лексику. Може вживати елементарні структури та завчені фрази, які демонструють дотримання культури мовлення і поведінки.

Письмо: може написати діловий лист з використанням формул мовленнєвого етикету. Може заповнити анкету, написати автобіографію. Може написати ділове повідомлення відповідно до поставленого завдання.

Високий рівень характеризується яскраво вираженою професійною спрямованістю та високим рівнем використання професійно значущих культурологічних знань, здатності до міжкультурного спілкування. За умови виникнення певних утруднень у тлумаченні культурологічних реалій здобувач освіти може без зусиль порозумітися зі співрозмовником, невимушено з'ясувавши їх значення. Здобувачі уміють створювати атмосферу взаєморозуміння і взаємодовіри у спілкуванні з представниками іншомовної культури. Здобувачі розуміють необхідність оволодіння іншомовною культурою, демонструють свідому зацікавленість у процесі міжкультурного спілкування та бажання подальшої самоосвіти, поповнення недостатніх знань.

За видами мовленнєвої діяльності високий рівень має такі характеристики:

Аудіювання: не має жодних утруднень у розумінні будь-якого мовлення живого чи запису на теми з кола власних чи професійних інтересів, які містять культурологічні матеріали. Може знаходити культурологічну інформацію відповідно до завдання.

Читання: може розуміти нескладні автентичні тексти, систематизувати та коментувати одержану інформацію. Має добрий набір безеквівалентної та фонової лексики, який дозволяє 
переглядати текст чи серію текстів з метою пошуку необхідної інформації для виконання певного завдання.

Говоріння: може брати участь у особистому та діловому спілкуванні з високим ступенем невимушеності і спонтанності, так щоб відбувалася природна інтеракція 3 представниками іншої лінгвокультури. Може повністю природно підтримувати розмову 3 тем, пов'язаних з рідною та іншомовною культурами, брати участь у спільній дискусії. Може швидко і спонтанно висловлюватись без очевидних утруднень у доборі культурологічно- маркірованої лексики. Може вільно спілкуватись у ситуаціях під час перебування у країні, мова якої вивчається, як на побутовому так i на професійному рівні з дотриманням культури ділового мовлення і ділового етикету.

Письмо: може передавати ділове повідомлення в короткому листі відповідного зразка або в довільній формі 3 дотриманням мовленнєвого етикету. Може написати відповідь на повідомлення такого типу.

3 метою діагностики рівня сформованості професійної іншомовної культурологічної компетентності майбутніх фахівців можна використовувати комплекс методик, розроблених фахівцями в галузі педагогіки та психології (зокрема, самооцінювання рівня сформованості професійної культурологічної іншомовної компетентності, анкетування 3 метою визначення значущості компонентів культурологічної компетентності. Авторські методики на предмет визначення рівня володіння культурологічним матеріалом складається з низки опитувань.

Для визначення рівня сформованості професійної іншомовної культурологічної компетентності за мотиваційним критерієм ми використовуємо методику, розроблену Інститутом комунікацій Ріда [7]. Здобувачі освіти визначають власні потреби у вивченні іноземної мови. за твердженнями.

1. Моя основна причина вивчення англійської - це задоволення / для моєї майбутньої роботи / інше (зазначте).

2. Я користуюся іноземною мовою, щоб розмовляти з носіями мови / не носіями мови.

3. Мені потрібна буде англійська для того, щоб розмовляти 3 зарубіжними партнерами, колегами / відповідати на телефонні дзвінки / розуміти та писати ділові листи / читати газети і журнали / читати фахову літературу / брати участь у переговорах, зустрічах 3 іноземними партнерами / інше (зазначте). 
4. Для цього, я вважаю, мені потрібно навчатися лексики / граматики / усного спілкування / писемного спілкування / іншомовної культури.

Для перевірки рівня сформованості професійної іншомовної культурологічної компетентності за когнітивним та діяльнісним компонентами ми пропонуємо анкету «Невербальні характеристики спілкування» [8, с. 148-150] та форму опитування Дж.Хейнс «What's in a gesture?» [9] з метою визначення наявності у здобувачів освіти уяви про невербальні паттерни рольової поведінки стосовно майбутньої професійної діяльності.

Зразок анкети «Невербальні характеристики спілкування» наведено нижче.

Шановний респонденте!

Як відомо, кожна людина використовує різні засоби для налагодження контакту з іншими людьми. Найпоширенішими засобами спілкування є мовленнєві і немовленнєві (міміка, жести, пози тощо). Нижче наведені немовленнєві характеристики поведінки в спілкуванні. Ваше завдання полягає в тому, щоб вибрати з запропонованого списку характеристик ті, які, на Вашу думку, відповідають певним нормам спілкування з діловими партнерами та колегами в рідній та англомовній культурах. На спеціальномулистку напишіть «Рідна культура», послідовно читайте, вибирайте $i$ ставте номер характеристики. Потім напишіть "Англомовна культура» і виконуйте завдання так само, як і в першому випадку.

\section{Список характеристик невербальної поведінки}

брати за руки; обіймати; цілувати; класти руки на плечі, шию тощо; якісь інші дотики (напишіть); дивитись в очі; дивитись в обличчя; дивитись на тіло; дивитись уважно; відводити очі в сторону під час зустрічі з очима партнера; інші характеристики погляду; оглядати іншу людину; сидіти, схрестивши руки на грудях, закинувши одну ногу на іншу; сидіти, трохи нахилившись уперед; сидіти, спершись на спинку стільця; сидіти прямо, поклавши руки на коліна, ноги разом; сидіти, поклавши руки перед собою; напружена поза; розслаблена поза; нахилити голову убік; підняти голову вгору; опустити голову вниз; втягнути голову в плечі; інші характеристики пози (написати); стискати руки попереду себе; стискати руки позаду себе; тримати руки в кишенях; прикривати рот рукою; торкатися різних частин обличчя; терти різні частини обличчя, тулуба; складати руки на грудях; інтенсивно жестикулювати; використовувати жести для того, щоб підкреслити сказане; використовувати 
жести для описання предметів; використовувати жести для вираження ставлення до іншого; тримати руки на бедрах; брати під руку; інші жести (напишіть); показувати радість; проявляти гнів; показувати подив; показувати страждання; показувати відразу; показувати захоплення; показувати зневагу; показувати страх; показувати любов; інші вирази обличчя (напишіть) говорити швидко; говорити повільно; голосно розмовляти; сміятися; плакати.

Опитування «What's in a gesture?»

Have participants number their papers from 1 to 10 . Make each gesture and ask them to write down what they think it means. Participants should also indicate if they think the gesture is considered rude in the United States? Have group discuss how body language influences communication between cultures.

1. Beckon with index finger.

2. Point at something in the room.

3. Make a "V" sign.

4. Smile.

5. Sit with sole of feet or shoe showing.

6. Form a circle with fingers to indicate «O.K.»

7. Hold up the right «pointer» finger with hand folded and facing away from body.

8. Pass an item to someone with one hand.

9. Wave hand with palm facing outward to greet someone.

10. Nod head up and down to say «Yes.»

Answer Key.

1. Beckon with index finger. This means «Come here» in the U.S. To use the finger(s) to call someone is insulting in many cultures. Expect a reaction when you beckon to a student from the Middle or Far East; Portugal, Spain, Latin America, Japan, Indonesia and Hong Kong. It is more acceptable to beckon with the palm down, with fingers or whole hand waving.

2. Point at something in the room. It is impolite to point with the index finger in the Middle and Far East. Use an open hand or your thumb (in Indonesia)

3. Make a "V" sign. This means "Victory" in most of Europe when you make this sign with your palm facing away from you. If you face your palm in, the same gesture means "Shove it".

4. Smile. This gesture is universally understood. However, it various cultures there are different reasons for smiling. The Japanese may smile when they are confused or angry. In other parts of Asia, people may smile 
when they are embarrassed. People in other cultures may not smile at everyone to indicate «Hello.» A smile may be reserved for friends.

5. Sit with soles shoes showing. In many cultures this sends a rude message. In Thailand, Japan and France as well as countries of the Middle and Near East showing the soles of the feet demonstrates disrespect. You are exposing the lowest and dirtiest part of your body so this is insulting.

6. Form a circle with fingers to indicate «0.K.» Although this means «O.K.» in the U.S. and in many countries around the world, there are some notable exceptions: - In Brazil and Germany, this gesture is obscene. - In Japan, this means «money.» - In France, it has the additional meaning of «zero» or «worthless.»

7. Hold up the right «pointer» finger with hand folded and facing away from body. In non-British countries of Europe, it can mean two of something. They start counting with the thumb. In Japan it would mean «four,» as the Japanese start counting with the pinkie.

8. Pass an item to someone with one hand. - In Japan this is very rude. Even a very small item such as a pencil must be passed with two hands. In many Middle and Far Eastern countries it is rude to pass something with your left hand which is considered «unclean.»

9. Wave hand with the palm facing outward to greet someone. In Europe, waving the hand back and forth can mean «No.» To wave "goodbye,» raise the palm outward and wag the fingers in unison, This is also a serious insult in Nigeria if the hand is too close to another person's face.

10. Nod head up and down to say «Yes.» In Bulgaria and Greece, this means «No.»

Для визначення рівня сформованості професійної іншомовної культурологічної компетентності майбутнього фахівця бізнессфери за особистісно-оцінювальним критерієм, на нашу думку доцільно використовувати метод самодіагностики, а саме нами була розроблена шкала самооцінювання. Десять дескрипторів здобувачі освіти оцінюють за п'яти бальною системою.

1. Я можу брати участь у спілкуванні 3 представниками англомовної культури

2. Я можу розуміти найважливіші відмінності між звичаями, звичками, цінностями та ідеалами, характерними для англомовної спільноти і власного народу

3. Я знаю і вмію застосовувати культуру ділового мовлення, діловий етикет

4. Я можу підтримувати розмову з тем, пов'язаних з рідною та англомовною культурами, брати участь у груповій дискусії/бесіді 
5. Я можу розпізнавати і розуміти культурологічні предмети і явища і за потреби з'ясовувати окремі деталі»

6. Я можу розуміти основний зміст адаптованого аудіо/відео запису, який містить культурологічні реалії.

7. Я можу виокремлювати загальну інформацію із прагматичних текстів (оголошення, меню, розклад руху поїздів, літаків тощо)

8. Я можу написати особистий лист з використанням формул мовленнєвого етикету.

9. Я можу заповнити анкету, написати автобіографію.

10. Я можу вільно спілкуватись у ситуаціях під час перебування у країні, мова якої вивчається, як на побутовому так і на професійному рівні з дотриманням культури ділового мовлення і ділового етикету.

Сформованість професійної іншомовної культурологічної компетентності за емпатичним критерієм пропонуємо перевіряти за допомогою «Шкали довіри», розробленої на основі шкали Розенберга [8] та анкети Дж. Роуз [10] на визначення міжкультурного усвідомлення.

Quiz on Intercultural Awareness

Working with different cultures requires sensitivity to cultural differences.

Test your intercultural awareness by answering true or false to each of the following statements:

1. A "thumbs up" in some Islamic countries is a rude sexual sign - true or false?

2. Forming an " $\mathrm{O}$ " with the thumb and the forefinger in Japan means that we can now discuss money - true or false?

3. Scandinavians are more tolerant to silent breaks in conversations true or false?

4. Laughter in Japan can be a sign of confusion, insecurity or embarrassment - true or false?

5. In the UK, to compromise is seen as a positive sign of both parties wining - true or false?

6. Wearing gloves in Russia when shaking hands is considered polite - true or false?

7. Leaving right after dinner in Central America is considered wellmannered as it means you've been well fed - true or false?

8. In Sub-Saharan Africa it is normal to arrive half an hour late for dinner - true or false?

9. If you tell your female friend from Africa that she's put on weight during her holiday, it means she's had a good holiday and is physically healthier than when she left - true or false? 
10. In Brazil, flicking your fingers under your chin is a sign of disgust true or false?

11. If you want to show your respect for an elder in Africa, do not look them directly in the eye - true or false?

12. Keeping your hands in your pockets while negotiating in Russia is rude - true or false?

13. It is seen as polite to not accept an offer of food or drink in Persia immediately on being offered it, instead you should refuse a few times before accepting the gift - true or false?

14. In France, dinner is commonly served at $5 \mathrm{pm}$ - true or false?

15. In Brazil, purple flowers are a symbol of friendship - true or false?

16. In Mediterranean cultures, being boisterous in the streets and public places is widely accepted - true or false?

17. In Australia, a single male passenger should sit in the back seat true or false?

(ANSWERS:1-5: True; 6: False - you need to remove your gloves when shaking hands in Russia; 7-9: True; 10: False - this means you don't know the answer to a question in Brazil; 11-13: True; 14: False - in France, it is common to eat dinner at $7 \mathrm{pm}$ or later and it tends to be a light dinner; 15: False - Purple flowers in Brazil are often seen at funerals. Avoid giving a host purple flowers; 16: True; 17: False - A single male passenger should sit in the front seat in Australia.)

Шкала довіри представникам іншомовної культури

1. Як Ви гадаєте, більшості представників іншомовної культури можна довіряти чи потрібно бути обережними у взаємодії з ними?

А. Більшості представників іншомовної культури можна довіряти.

В. У взаємодії з представниками іншомовної культури потрібно бути обережними.

2. Чи могли б Ви стверджувати, що представники іншомовної культури частіше прагнуть бути корисними іншим, чи вони думають лише про себе?

А. Прагнуть бути корисними іншим.

В. Думають лише про себе.

3. Як Ви гадаєте, більшість представників іншомовної культури намагалися б ошукати Вас, якби у них випала така нагода, чи вони поводили б себе чесно?

А. Намагалися б ошукати, якби у них випала така нагода.

В. Поводили б себе чесно.

(Ключ до «Шкали довіри»: Якщо відповідь респондента збігається 3 ключем, вона оцінюється в 1 бал, якщо ні - 0 балів: 1 - А; 2 - А; 
3 - В. Бали додаються: 1 бал - низький показник довіри; 2 бали середній показник довіри; 3 бали - високий показник довіри).

\section{Висновки}

У ході вивчення та узагальнення дидактичної літератури виявлено, що здобувач вищої освіти повинен: володіти широким спектром культурологічних знань, які забезпечують можливість орієнтуватись у соціокультурних маркерах; уміти розпізнавати та розуміти різницю між сприйняттям іншої культури та культури свого народу; уміти прогнозувати можливі культурологічні перешкоди в умовах міжкультурного професійного спілкування і знаходити шляхи їх усунення; розглядати свою країну в аспекті перетину культур; демонструвати культурну толерантність; бути підготовленим до культурної адаптації; розуміти особливості поведінки представників іншомовної культурної спільноти в ділових ситуаціях.

На нашу думку, культуровідповідна професійна іншомовна освіта має на меті формування у здобувачів освіти професійної іншомовної компетентності, яка передбачає:

- адекватну реакцію на мовленнєві і немовленнєві коди співрозмовника;

- орієнтування в міжкультурній ситуації у сфері ділового спілкування, передбачення можливих культурологічних перешкод і подолання їх;

- подолання міжкультурних непорозумінь і конфліктних ситуацій;

- порівняння значень культурологічних категорій у різних культурах;

- толерантне ставлення до іншої культури;

- розпізнавання та правильний добір лексичних одиниць 3 національно-культурним компонентом;

- адекватне використання культурологічних знань в ситуаціях міжкультурного ділового спілкування;

- прогнозування можливої мовленнєвої та немовленнєвої поведінки ділового партнера.

У ході дослідження визначено критерії та показники діагностування рівнів сформованості професійної іншомовної культурологічної компетентності здобувачів. Критерії оцінювання відображають компонентний склад професійної іншомовної культурологічної компетентності і складаються з п'яти блоків: мотиваційного, когнітивного, діяльнісного, особистісно-оцінювального, емпатичного. 
На основі визначених критеріїв та їх характеристик виділено високий, середній та низький рівні сформованості професійної іншомовної культурологічної компетентності майбутнього фахівця та ілюстративні дескриптори для всіх видів мовленнєвої діяльності.

\section{Література}

1. Першукова 0.0. Концептуальна модель соціокультурної складової змісту навчання іноземної мови в європейських країнах. Педагогіка і психологія, 2003. №3-4. С. 155-161.

2. Агадуллін Р.Р. Полікультурна освіта: методолого-теоретичний аспект. Педагогіка і психологія, 2004. №3. С. 18-29.

3. Бушкова В. Креативність нелінійного мислення у багатомовному та полікультурному навчальному просторі. Вища освіта України, 2003. №2. С. 120-125.

4. Загальноєвропейські Рекомендації з мовної освіти: вивчення, викладання, оцінювання / науковий редактор українського видання доктор пед. наук, проф. С.Ю. Ніколаєва. К. : Ленвіт, 2003. 273 с.

5. R.G. D'Andrade The Cultural Part of Cognition URL: https:// onlinelibrary.wiley.com/doi/abs/10.1207/s15516709cog0503_1

6. Падалка О. Зміст освіти в національній школі України. Пед. технології. К, 1995. С. 24-27.

7. Communicating in the global village: Cross-cultural Knowledge Assessment. Reed Institute of Communication. URL: www. globalconnectionstraining.ca/pdfs/culturalneedassessment.pdf

8. Лабунская В.А. Психология затрудненного общения. М. : ACADEMIA, 2001. $286 \mathrm{c}$.

9. Haynes Judie What's in a Gesture? URL: www.everythingesl.net/ downloads/gestures_version02.pdf

10. Rose Joni Quiz on Intercultural Competence. URL: www. skillassessment.suite.101.com/.../quiz_on_intercultural_competence 